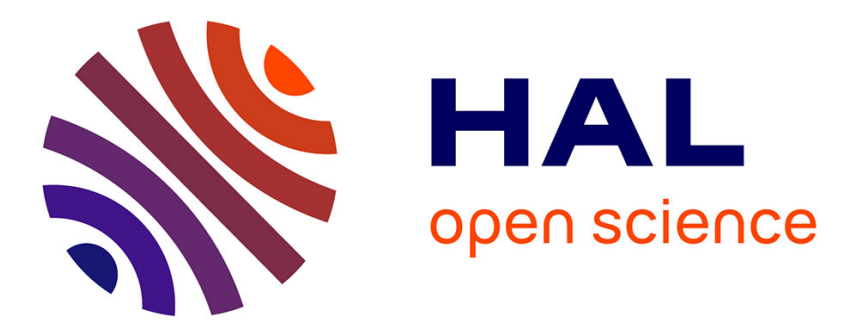

\title{
Echo-guided percutaneous approach to the internal jugular vein for implantable portacath
}

\author{
A. Pinto, M. Pocard
}

\section{To cite this version:}

A. Pinto, M. Pocard. Echo-guided percutaneous approach to the internal jugular vein for implantable portacath. Journal of Visceral Surgery, 2019, 156, pp.147 - 151. 10.1016/j.jviscsurg.2018.11.003 . hal-03486477

\section{HAL Id: hal-03486477 \\ https://hal.science/hal-03486477}

Submitted on 21 Dec 2021

HAL is a multi-disciplinary open access archive for the deposit and dissemination of scientific research documents, whether they are published or not. The documents may come from teaching and research institutions in France or abroad, or from public or private research centers.
L'archive ouverte pluridisciplinaire HAL, est destinée au dépôt et à la diffusion de documents scientifiques de niveau recherche, publiés ou non, émanant des établissements d'enseignement et de recherche français ou étrangers, des laboratoires publics ou privés.

\section{다)(1) $(5$}

Distributed under a Creative Commons Attribution - NonCommerciall 4.0 International 
Pose d'une chambre à cathéter implantable par abord per cutané de la veine jugulaire interne, écho guidée

Placement of an implantable catheter chamber by percutaneous approach of the internal jugular vein, guided per echo

Amandine PINTO (1), Marc POCARD

1 Université Paris Diderot, Sorbonne Paris Cité, AP-HP, Hôpital Lariboisière, Chirurgie Digestive et Cancérologique, Paris, France

Correspondance :

Pr Marc Pocard, Hôpital Lariboisière, Chirurgie Digestive et Cancérologique. 2 rue Ambroise Paré, 75475 Paris CEDEX 10, France.

Tel : $0149958258 \quad$ Fax : 0149959102 Mail : marc.pocard@gmail.com 


\section{Echo-guided percutaneous approach to the internal jugular vein for implantable portacath}

\section{Introduction}

Portacath implantation is indicated for two major reasons: therapy (chemotherapy, parenteral nutrition, long-term intravenous antibiotic administration for immunocompromised patients) and patient comfort (inadequate peripheral veins, repeated venipunctures).

For many years, surgeons have favored the technique of open exposure of the jugular vein or access via the cephalic vein [1]. However, percutaneous catheter insertion into the internal jugular vein under ultrasound control is currently the preferred approach in view of the speed of the procedure (25 min on average) and the low rate of thrombosis. Although this is not a strict recommendation, the HAS (French High Health Authority-Haute Autorité de Santé) highlights the advantages of the percutaneous technique and recommends the right side for anatomical reasons. Anesthesiologists were the first to promote the interest of ultrasound guidance to aid in the placement of central venous catheters, in light of the accuracy, rapidity of the gesture, post-procedural complications and patient comfort [2-4].

Contraindications should be ruled out beforehand, e.g. intra-jugular thrombosis along the course of a central catheter, extrinsic tumor compression resulting in a superior vena caval syndrome, tumor invasion of the vein.

We describe the procedure for an echo-guided percutaneous catheter insertion into the right internal jugular vein.

\section{Installation (Figure 1)}

The patient lies supine with the right arm alongside the body. The operator stands on the patient's right side with the ultrasound system and video monitor 
placed on the patient's left, facing the operator. The C-arm fluoroscopy unit must be in the room to avoid prolonging the intervention, especially in case of local anesthesia.

Before skin preparation and draping, a preliminary ultrasound exam is essential to identify the jugular vein and verify its patency. Placement of the patient in slight Trendelenburg position will increase the diameter of the target vein.

\section{Ultrasound-guided venipuncture (Figure 2)}

Local anesthesia is obtained by infiltration of $1 \%$ lidocaine into the anticipated site of cervical puncture, as well as the future site of the portacath reservoir placement and along the intervening course of subcutaneous tunneling between these two sites.

With the head turned to the left, the right internal jugular vein is identified by ultrasound. The probe is positioned parallel to and one $\mathrm{cm}$ (or fingerbreadth) above the clavicle. This provides a cross section of the carotid artery and internal jugular vein. The vein lies anterior and lateral to the carotid; unlike the artery, it is compressible when pressure is applied by the overlying probe. The venipuncture is performed using the dedicated needle from the portacath kit, connected to a $10 \mathrm{cc}$ syringe with constant aspiration applied. If the syringe plunger rises spontaneously without the need for aspiration, the needle has probably entered the carotid artery. It is then advisable to withdraw and compress the puncture site for 5 to 10 minutes. Further attempts at venipuncture cannot be renewed at this location, and the catheter will have to be inserted at another venous site.

\section{Guidewire passage (Figure 3)}


Once venous blood return is obtained, the syringe is disconnected and the guidewire is threaded into the needle. The mobilization of the patient's right shoulder can facilitate the advancement of the guide into the superior vena cava, which is verified under fluoroscopic control.

\section{Dilator passage (Figure 4)}

After checking that the introducer slides correctly in its peel-away sheath, the dilator and sheath are threaded onto the guide wire and advanced through the needle puncture site (which has been enlarged at skin level to allow passage of the $3 \mathrm{~mm}$ introducer assembly). The peel-away sheath is then held in position while the dilator and the guidewire are removed.

\section{Catheter placement (Figure 5)}

The catheter is then rapidly introduced into the sheath and advanced into the superior vena cava. Once the catheter is well advanced, the sheath is peeled away. If, by misadventure, a carotid artery puncture has been dilated, the sheath must be left in place with the dilator placed inside, in order to stop the bleeding while a vascular surgeon is contacted.

\section{Fluoroscopic control (Figure 6)}

Fluoroscopy verifies that the catheter is well positioned. Its tip must not extend beyond the level of the right main stem bronchus. This length is then noted thanks to the graduations marked on the catheter, allowing the catheter to be pushed back to its correct position after preparation of the subcutaneous reservoir pocket and threading of the proximal catheter through the subcutaneous tunnel. 


\section{Creating a pocket for the implantable reservoir and subcutaneous tunneling (Figure 7)}

A $3 \mathrm{~cm}$. transverse skin incision is made $6 \mathrm{~cm}$ (about 3 fingerbreadths) below the clavicle. Cutaneous and subcutaneous tissues are dissected down to the pectoral fascia to create a pocket large enough to receive the reservoir. Careful hemostasis is performed to prevent hematoma in the pocket.

The tunneling system provided in most kits is sharp at one end that can be connected to the catheter. The sharp end is inserted into the apex of the subcutaneous pocket and pushed through the intervening subcutaneous tissue to the site of the cervical puncture site. The catheter is then affixed to the pointed end of the tunneler and the assembly is drawn down into the pocket. The length of catheter within the vein is carefully verified by the catheter markings. The proximal catheter is drawn down into the pocket and any excess length is trimmed before connecting the catheter to the reservoir (Figure 8). The reservoir must be pre-filled with saline. Two 2-0 Vicryl $\AA$ sutures are passed through each of the 2 phlanges. The catheter is then cut to the desired length with scissors and the connecting ring is slid over the catheter and its wide end locks the catheter in place after connection to the reservoir. The reservoir is then seated in its pocket and anchored to the pectoral fascia with the previously placed sutures. If the reservoir is anchored with only one suture, the risk of the reservoir overturning is increased. The pocket is closed by a sub-cutaneous layer of interrupted 2-0 Vicryl $\circledast$ sutures and a cutaneous closure of interrupted resorbable 3.0 Monocryl $\AA$ or rapidly absorbable 3-0 Vicryl $\AA$. Interrupted sutures are favored. The cervical wound is then closed with an absorbable stitch. The port is accessed trans-cutaneously. After aspiration to demonstrate venous return, it is then flushed with saline to guarantee free flow. A chest $x$-ray is performed post-operatively before use of the portacath.

\section{References:}


[1] Jouvin I, Pocard, Haythem N. Mise en place d'une chambre à cathéter implantable par abord de la veine céphalique. J Chir 2018 in press (JCHIR-18153R1)

[2] Peris A, Zagli G, Bonizzoli M, et al. Implantation of 3951 long-term central venous catheters: performances, risk analysis, and patient comfort after ultrasound-guidance introduction. Anesth Analg 2010; 111: 1194-201

[3] Wu SY, Ling Q, Cao LH, Wang J, Xu MX, Zeng WA. Real-time twodimensional ultrasound guidance for central venous cannulation: a metaanalysis. Anesthesiology 2013; 118: 361-75

[4] Gurien LA, Blakely ML, Crandall MC, et al. Meta-analysis of surgeonperformed central line placement: Real-time ultrasound versus landmark technique. J Trauma Acute Care Surg 2018; 84: 655-63 


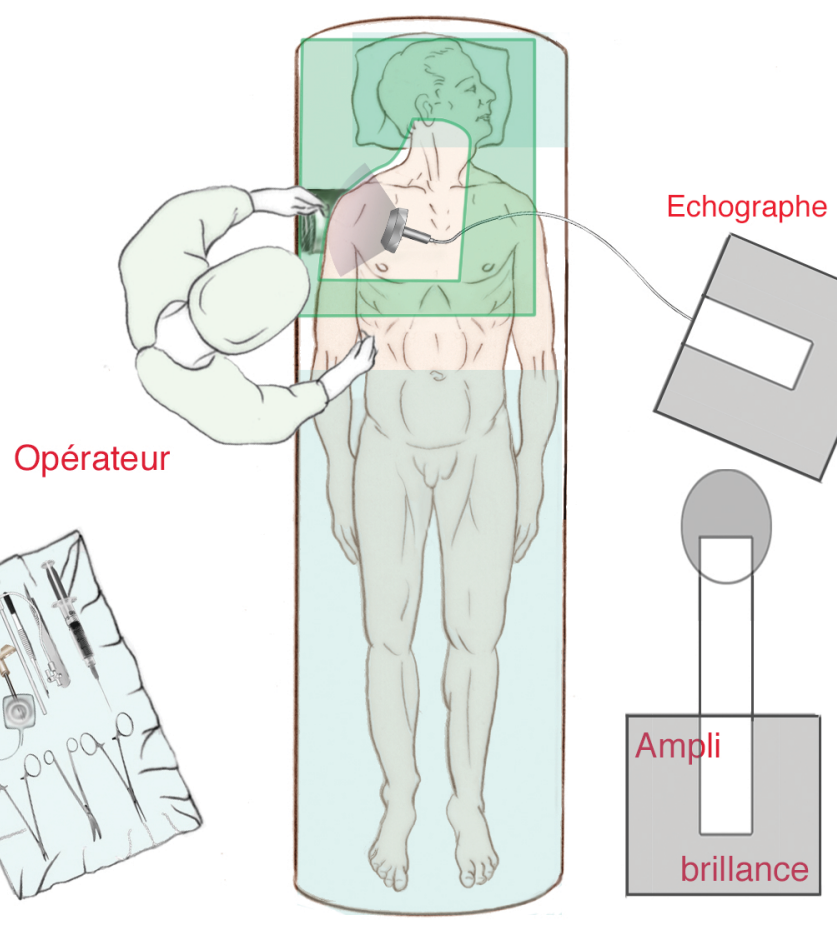




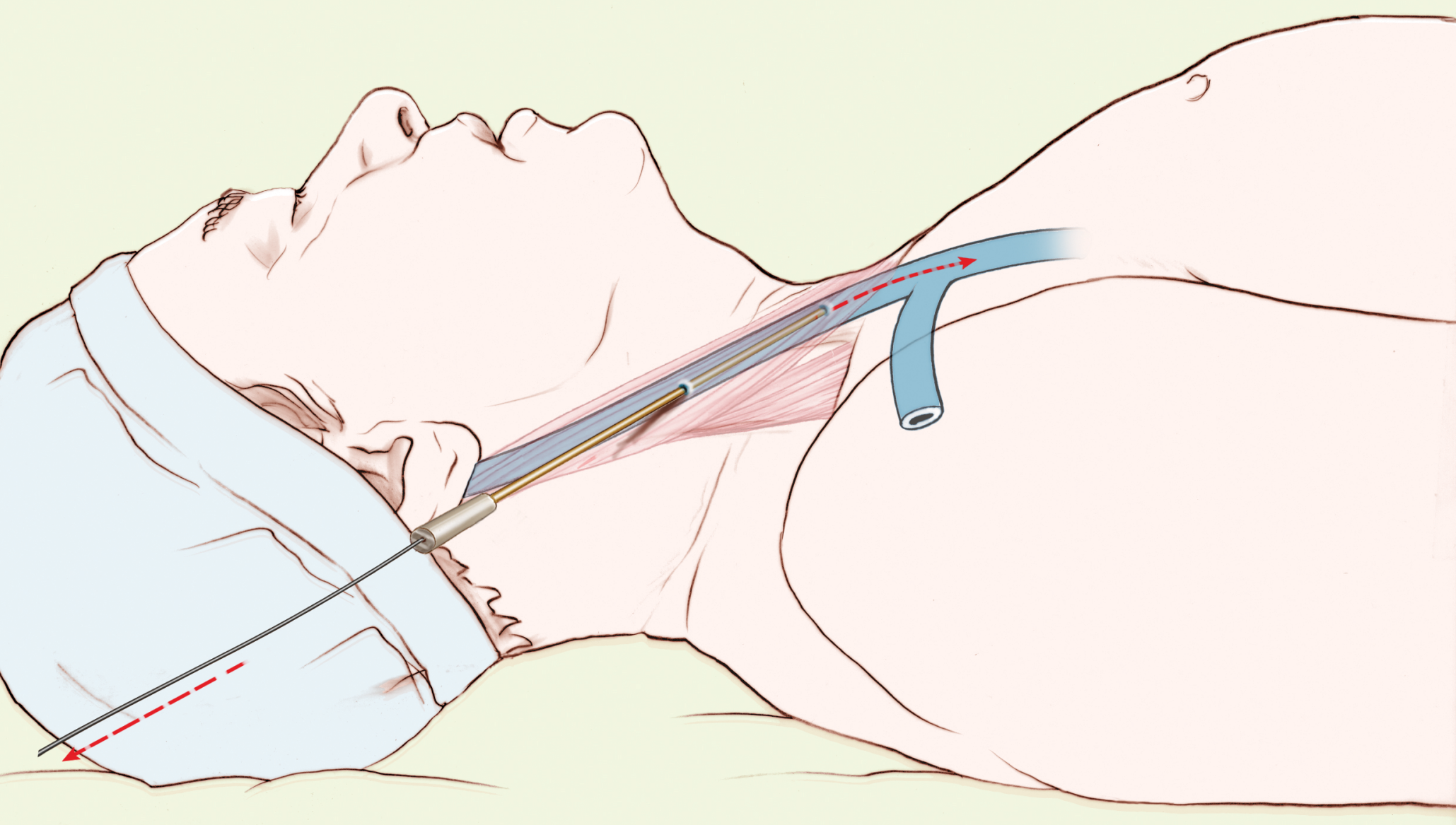




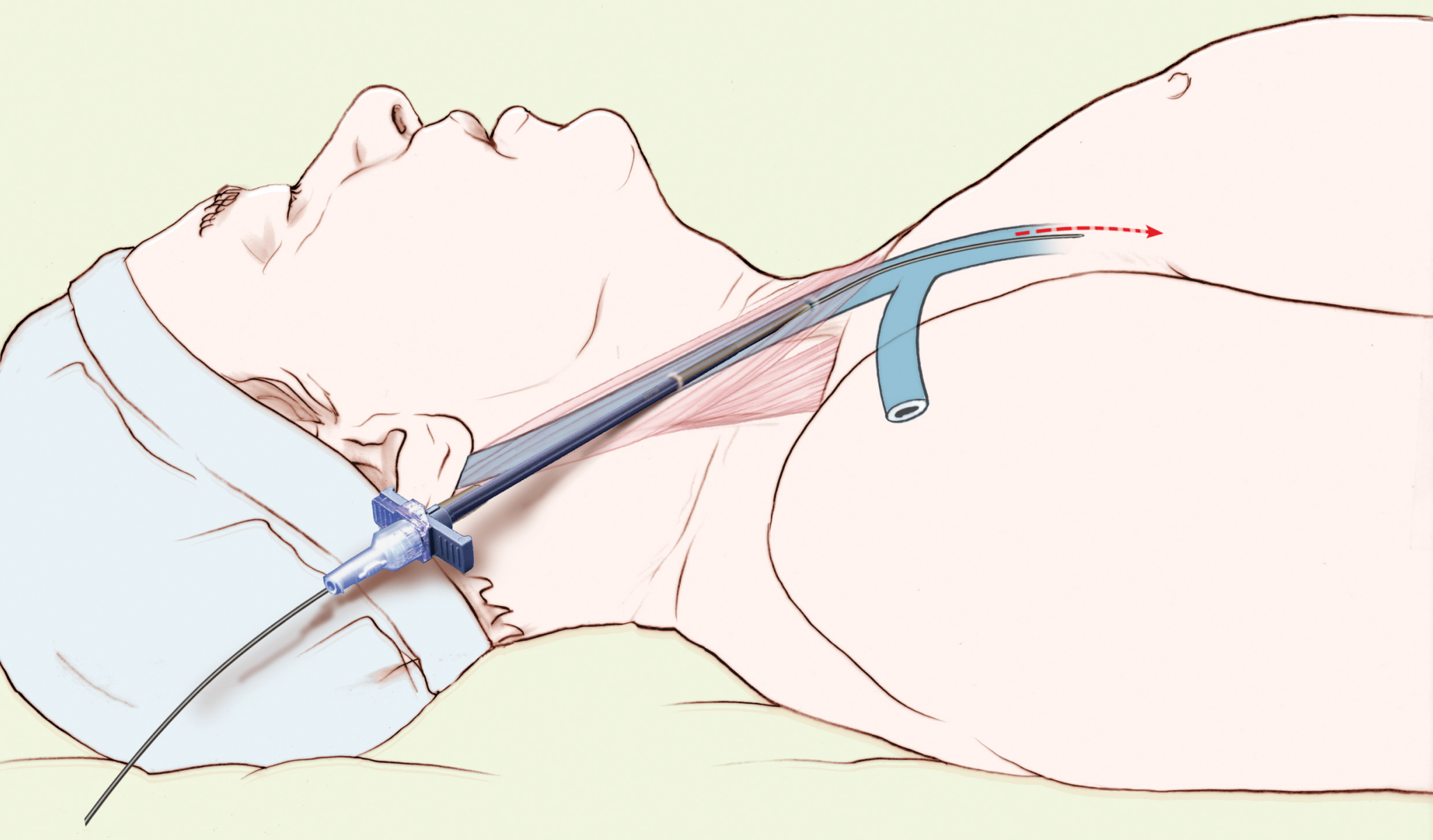




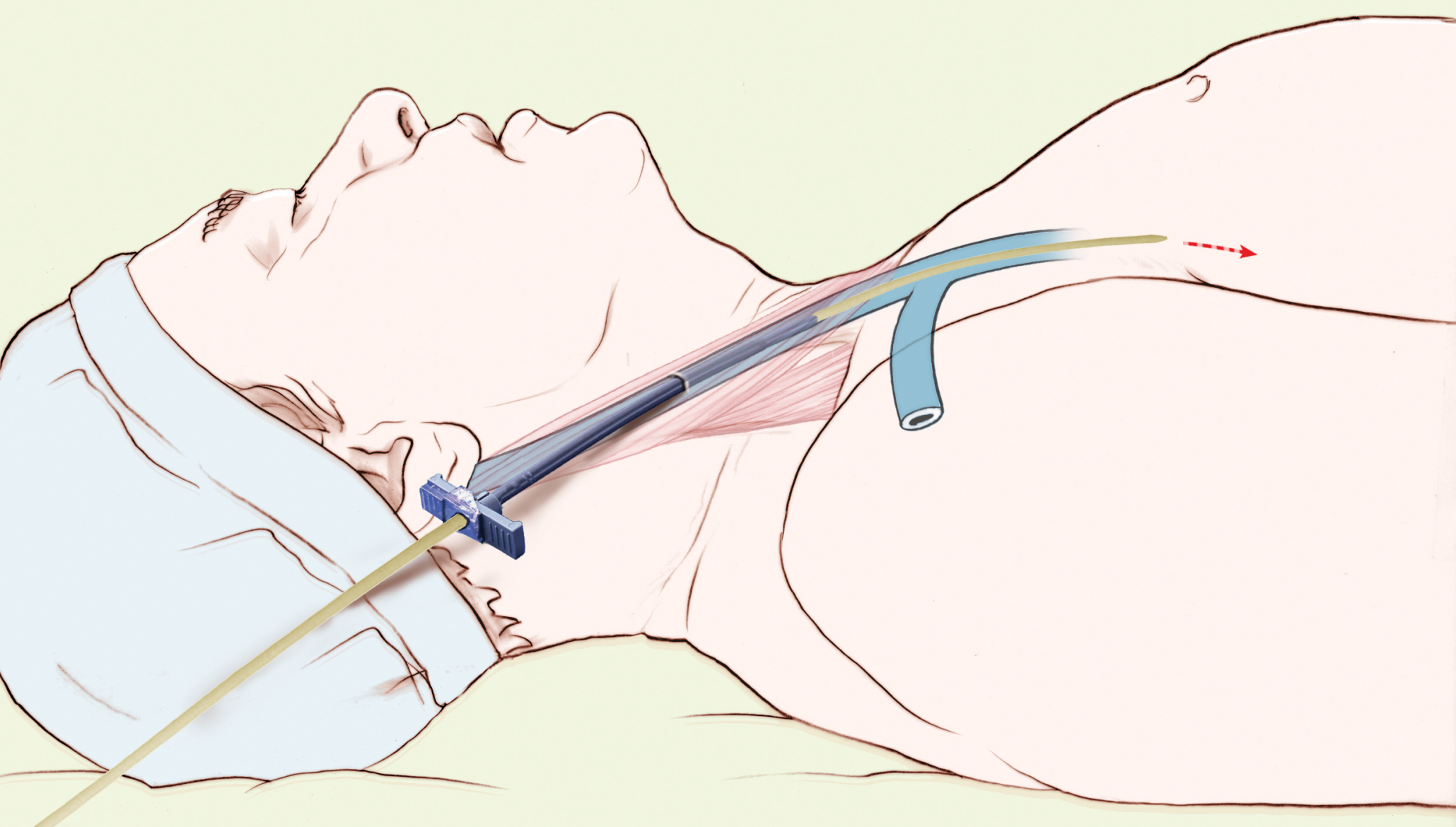





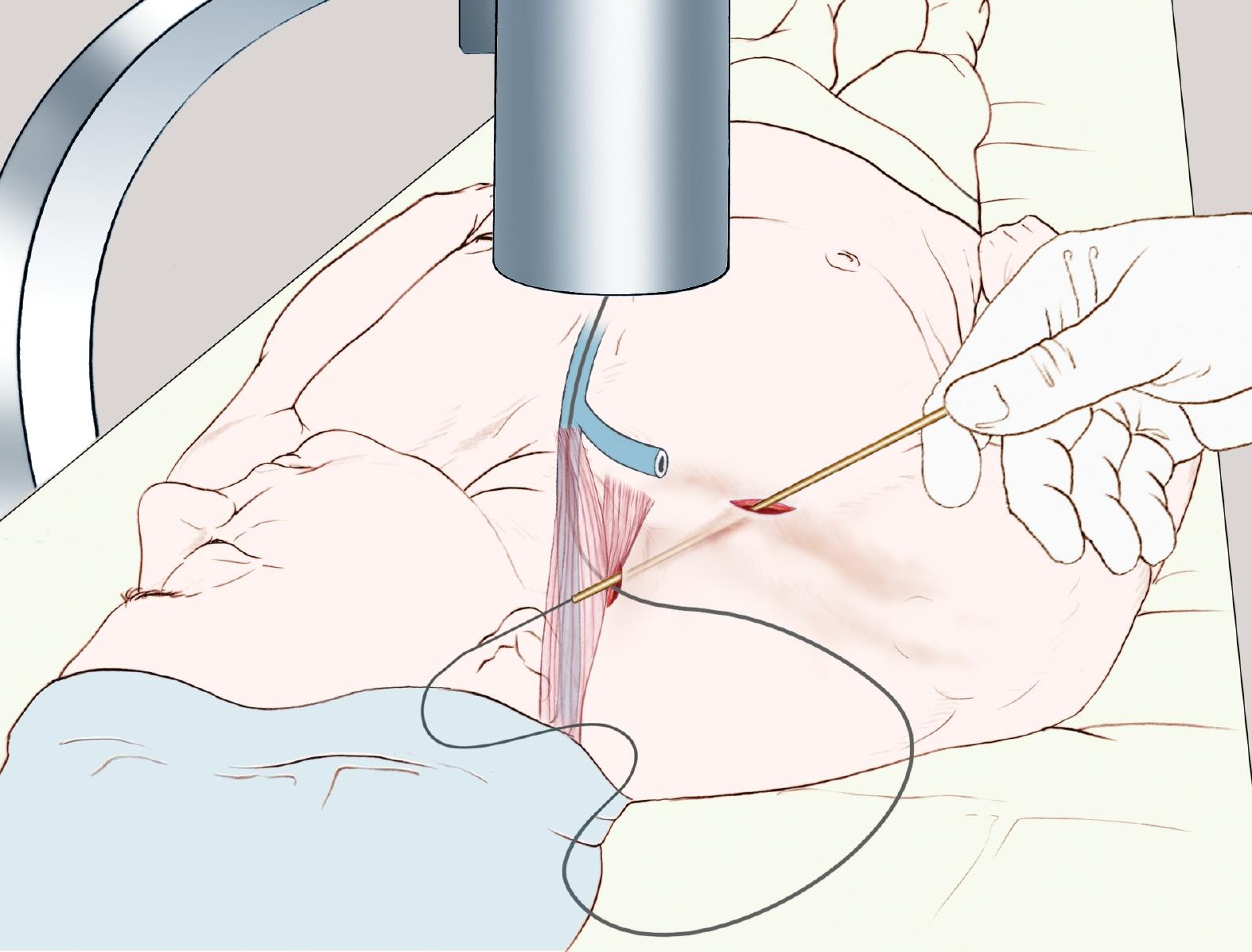




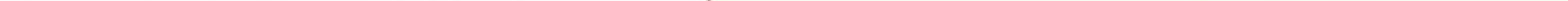

